It is represented by two species-one, Parascaptor leucuras, Blyth, found in Tenasserim and Sylhet; the other, P. lepturus, Thomas, discovered in China.

4. The genus Scaptochirus, which I made known in 1867 , consists only of a single species, forming part of the collections made in China by the Abbé A. David. It is Scaptochirus moschatus. It is characterized by the number of premolars, which is reduced to three in each jaw. Its dental formula is therefore-

$$
\text { I. } \frac{3-3}{3-3} \text {, C. } \frac{1-1}{1-1} \text {, PM. } \frac{3-3}{3-3} \text {, M. } \frac{3-3}{3-3},=40 \text { teeth. }
$$

The investigation that I have just made of various species belonging to these groups has proved to me that, in giving them the rank of genera, we have exaggerated their zoological value, and that they must be regarded only as subgenera. The discovery of a new species, intermediate in its characters between Scaptochirus and Parascaptor, would indeed suffice to prove this.

This species was discovered in the neighbourhood of Akbès, on the confines of Syria and Asia Minor, by the Abbé A. David. By the number of its premolars it resembles Scaptochirus and differs from Talpa; but the form of the molars, the small development of the last premolar, and the narrowness of the face approximate it to the Moles, and especially to Parascaptor. The lower jaw presents an anomaly, which shows how little importance should be attached to the number of the small incisiform teeth, including the true incisors and the canines. In fact, on the right side there are four of these teeth, and on the left side we can only count three; so that, on the right, the arrangement of the anterior teeth is that of the Common Mole and of Scaptochirus, while on the left it is identical with that of Mogera.

I have named this species Scaptochirus Davidianus, to recall the name of our learned Correspondent; it differs very little in its aspect from the European moles. Its size is smaller, an adult male individual only measuring 0.12 metre; the tail is short, its length being 0.02 . The muzzle is pointed; all over the body the hair is thick, velvety, and of a grey colour, approaching black. The habits of this animal are the same as those of our mole; but it is completely blind; the eyelids do not open, but extend over the globe of the eye, the dimensions of which are much reduced, as in the Italian Talpa creca.-Comptes Rendus, December 29, 1884, p. 1141.

\title{
Biological Evolution of the Aphides of the Genus Aphis.
} By M. Lichtenstein.

I have at various times brought before the Academy the evolutional cycle of various Aphides of the tribes Phylloxerinæ and Pemphiginæ, and have indicated, in the case of the latter, curious migrations from the galls of trees to the roots of grasses. Recently, in the 'Comptes Rendus' of November 10, 1884, I described the biology of the maple Aphis (Chaitophorus aceris), which, without quitting the tree on which it was born, passes three months under an anomalous form, benumbed in a lethargic slumber, only to become developed towards the autumn and produce sexual individuals. 
At the same time I have carefully examined various other Aphides of the group of true Aphidinæ with long 7-jointed antennæ. The following is what I have observed :-

The false female, or foundress pseudogyne, which issues from the egg in the spring, always remains apterous. In from twenty to thirty days it produces living young, most of which continue apterous, while some acquire wings. These two forms, which are generally deficient among the Pemphiginæ, become fitted to bud in their turn in about the same length of time (about a month), and then all the individuals produced either by the apterous or by the winged forms acquire wings and quit the cradle of the family.

Where they go I have not yet been able to discover; but the fact is, that at the end of June all the Aphidinæ have disappeared and none or very few of them are to be found on the trees and bushes.

Although I have been unable to trace this emigrant pseudogyne, which leaves a regrettable gap in the evolution, I have in autumn met with the pupiferous pseudogyne, which, just as in the case of the Pemphiginæ, returns to convey the sexual forms to the tree upon which they are to copulate and leave the eggs which will produce the foundress in the ensuing spring.

The Aphides that I have been able to observe are as follows :Aphis atriplicis, A. avence, A. craccivora, A. donacis, A. evonymi, A. frangule, A. mali, A. padi, A. persica, A. pyri, A. viburni, Siphonophora absinthii, Rhopalosiphum persica, Hyalopterus pruni.

Quite unlike the sexual forms of the Pemphiginæ, little creatures without either wings or rostrum, the sexual forms of the Aphidinæ have a rostrum, and, with rare exceptions (A. mali, S. absinthii), the males are winged, but the females are always apterous and lay several eggs, while among the Pemphiginæ and Phylloxerinæ the egg is single.

I should not have made this incomplete communication to the Academy if M. Kessler, of Cassel, who is occupied with the same studies as myself, had not made a communication to the LeopoldinoCaroline Academy upon the same subject*. His observations are identical with mine, and relate in great part to the same insects :A. padi, A. evonymi, A. viburni, A. mali, A. pyri, A. sambuci. As he does me the honour to adduce these facts as a confirmation of my theory of the biological evolution of the Aphides, I must say, in my turn, how happy I am to see such earnest observers as II. Kessler bringing their aid to the investigation of those terrible enemies of our crops which are known as Aphides.-Comptes Rendus, December 29, 1884, p. 1163.

* Nova Acta Acad. Leop.-Carol. Nat. Cur. xlvii. no. 3. 


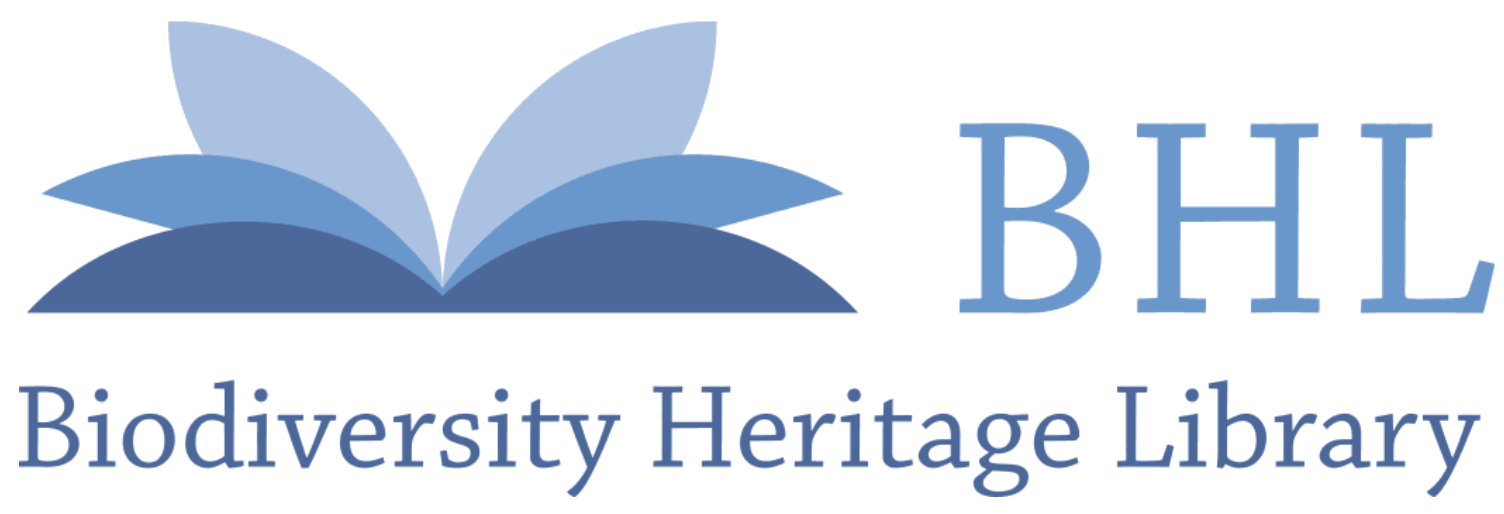

Lichtenstein, Jules. 1885. "Biological evolution of the aphides of the genus Aphis." The Annals and magazine of natural history; zoology, botany, and geology 15, 155-156. https://doi.org/10.1080/00222938509459314.

View This Item Online: $\underline{\text { https://www.biodiversitylibrary.org/item/53785 }}$

DOI: https://doi.org/10.1080/00222938509459314

Permalink: https://www.biodiversitylibrary.org/partpdf/53192

\section{Holding Institution}

Smithsonian Libraries

\section{Sponsored by}

Smithsonian

\section{Copyright \& Reuse}

Copyright Status: Public domain. The BHL considers that this work is no longer under copyright protection.

This document was created from content at the Biodiversity Heritage Library, the world's largest open access digital library for biodiversity literature and archives. Visit BHL at https://www.biodiversitylibrary.org. 